\title{
Comment on: 'COUP-TFII regulates metastasis of colorectal adenocarcinoma cells by modulating Snail1'
}

P-P Bringuier ${ }^{1,2,3}$ and L A Giroldi ${ }^{*}, 1$

${ }^{1}$ INSERM, U865, IFR62, F-69 372 Lyon, France; ${ }^{2}$ Université Claude Bernard Lyon1, F-69622 Villeurbanne, France and ${ }^{3}$ Lyon Cancer Research Center, UMR 1052, INSERM, 69 372, Lyon cedex 08, France

Sir,

We read with great interest the paper by Bao et al (2014) entitled 'COUP-TFII regulates metastasis of colorectal adenocarcinoma cells by modulating Snail1', showing upregulation of Snail and downregulation of E-cadherin in the human epithelial intestinal cell line HIEC overexpressing COUP-TFII upon transfection (Bao et al, 2014; Figure 5) and converse effects in COUP-TFII-KO loVo cells

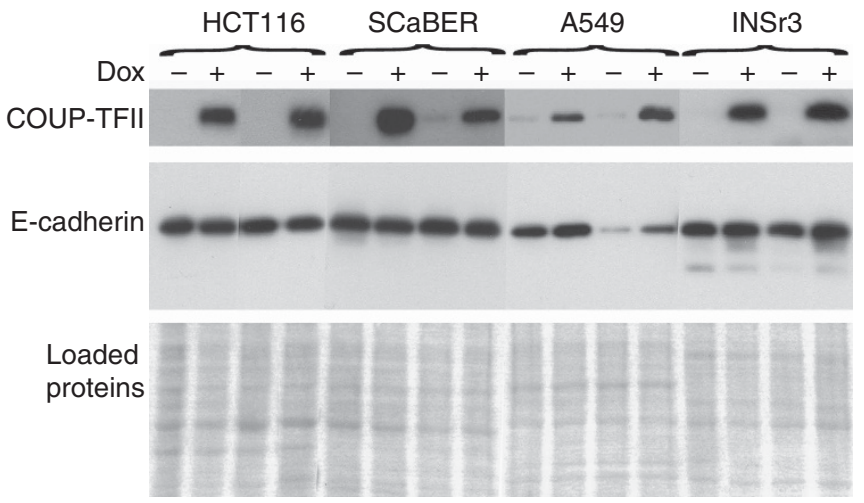

Figure 1. Expression of E-cadherin in cell lines overexpressing COUP-TFIl upon transfection. HCT116 (human colon carcinoma), SCaBER (human bladder squamous carcinoma), A549 (human lung carcinoma) and INS (rat insulinoma) cell lines were treated with doxycyclin $(+)$ to induce COUP-TFII expression. Two different clones are shown for each transfected cell line. COUP-TFII and E-cadherin expression was evaluated by western blotting using $20 \mu \mathrm{g}$ of total protein extracts. Equal loading was checked by staining the membrane with amidoblack.

(Bao et al, 2014; Figure 4). We previously explored the role of COUPTFII as a regulator of E-cadherin expression because we also had noticed a correlation between abnormally high expression of COUPTFII and lack of E-cadherin in a large panel of carcinoma cell lines of various origins including 22 colon cancer cell lines. We transfected several cell lines with an inducible COUP-TFII expression vector and, as shown in Figure 1, did not observe a pronounced effect on E-cadherin expression. In the human colon carcinoma line HCT116 in particular, E-cadherin remained perfectly stable. HCT116 cells are not invasive in Matrigel assays and invasion was not induced by COUP-TFII. Importantly, in the lung carcinoma line A549 that is invasive straightaway, E-cadherin expression was moderately increased together with, as previously reported (Navab et al, 2004), the invasion capacity of the cells. We also extinguished COUP-TFII expression in E-cadherin-negative cell lines (SW800, MDA-MB 231) using RNA interference and saw no E-cadherin switch-on. Together with the data from Bao et al, this shows that the effect of COUP-TFII is highly dependent on the cellular context. This is actually not very surprising since transcriptional regulation by COUP-TFII is quite complex, involving dimerisation and recruitment of cofactors, and can encompass not only activation but also direct and indirect repression (Park et al, 2003).

\section{REFERENCES}

Bao Y, Gu D, Feng W, Sun X, Wang X, Zhang X, Shi Q, Cui G, Yu H, Tang C, Deng A (2014) COUP-TFII regulates metastasis of colorectal adenocarcinoma cells by modulating Snaill. Br I Cancer 111: 933-943.

Navab R, Gonzalez-Santos JM, Johnston MR, Liu J, Brodt P, Tsao MS, Hu J (2004) Expression of chicken ovalbumin upstream promoter-transcription factor II enhances invasiveness of human lung carcinoma cells. Cancer Res 64: 5097-5105.

Park JI, Tsai SY, Tsai MJ (2003) Molecular mechanism of chicken ovalbumin upstream promoter-transcription factor (COUP-TF) actions. Keio J Med 52: $174-181$

*Correspondence: Dr LA Giroldi; E-mail: laurence.giroldi@inserm.fr Published online 9 December 2014

(c) 2015 Cancer Research UK. All rights reserved 0007-0920/15

http://creativecommons.org/licenses/by-nc-sa/3.0/

BJC $\cap$ OPEN 0

\section{Comment on 'Updated investigations of cancer excesses in individuals born or resident in the vicinity of Sellafield and Dounreay': premature all-clear for nuclear power}

I Fairlie*,1 and A Körblein ${ }^{2}$

${ }^{1} 115$ Riversdale Road, London N5 2SU, UK and ${ }^{2}$ Untere Söldnersgasse 8, 90403 Nürnberg, Germany

Sir,

Bunch et al (2014) report no increased leukaemia/cancer rates in children and young adults below age 25 in Seascale ward near the Sellafield nuclear site, during the period 1991-2006. But the case numbers are very small -1 observed leukaemia case $(O=1)$ vs 0.26 expected cases $(E=0.26)$, which means a standardised incidence ratio (SIR) of 3.9 with a wide $90 \%$ confidence interval (90\% CI: $0.28-33.8$ ). Near the Dounreay nuclear installation, in the wards of Thurso and Reay, not a single leukaemia case was registered in 1991-2006, and also not in the respective control region, the rest of Caithness county. Thus, for 1991-2006, no meaningful conclusions about leukaemia risk near Sellafield and Dounreay can be drawn from these numbers.

Bunch et al fail to discuss the leukaemia increases over the full period, 1963-2006. A highly significant increase is found in Seascale ward $(O=6, E=0.91, \operatorname{SIR}=6.67,90 \% \mathrm{CI}: 2.9,13.0)$. The ratio of the SIR in Seascale $(\mathrm{SIR}=6.67)$ to the SIR in Copeland and Allerdale County excluding Seascale $(\mathrm{SIR}=0.90)$ yields a relative risk $(\mathrm{RR})$ of $\mathrm{RR}=6.67 / 0.90=7.4 \quad(P=0.0002)$. Near Dounreay the increase in leukaemia risk is not significant $(\mathrm{RR}=1.64, P=0.227)$. For all malignancies and over the whole study period 1963-2006 a significantly increased risk is found near Sellafield $(R R=3.3$, $P=0.0004)$, but the increase is not statistically significant near Dounreay ( $\mathrm{RR}=1.22, P=0.274)$.

Pooled data from Sellafield, Dounreay, and La Hague: Guizard et al (2001) reported on leukaemia around the La Hague reprocessing plant in France between 1978 and 1998. Leukaemia rates in the 10-km zone were compared with rates in the $10-35-\mathrm{km}$ zone. During the 21 -year study period, four leukaemia cases were found among children in the $10-\mathrm{km}$ 